\title{
COVID19 IMPACT ON CHANGING THE BUSINESS ENVIRONMENT AND GOOD PRACTICE EXAMPLES IN HOTEL INDUSTRY IN BELGRADE
}

\author{
Ana Aleksići \\ Obren Drljević2, \\ Zoran Knežević ${ }^{3}$ \\ ${ }^{1}$ Event Planner doo, \\ Belgrade, Serbia \\ ${ }^{2}$ College of Tourism, \\ Belgrade, Serbia, \\ JP Srbijašume \\ ${ }^{3}$ Crowne Plaza Hotel, \\ Belgrade, Serbia
}

\begin{abstract}
:
Under the influence of many external and internal factors, growth and development of a company are not always straightforward or upward. No other issue as a crisis management is at the moment so interesting subject for researchers as all other theories are now not applicable if the key variables for overwhelming covid19 crisis are not conducted. Only flexible organizations, proactive managers and quick reaction can help a company doing business in hospitality industry today. The focus of this paper is to examine the relationship among crisis management practices with new product and new ideas as a reactive approach and repercussion on occupancy rate and image improvement among Belgrade hotels. Hotels in Belgrade are highly affected by the crisis; even now less than $30 \%$ of them are open, facing low occupancy rates and low profits. On the other hand, this could be seen as an opportunity for individuals to show exceptional managerial capabilities. This paper deals mainly with the actions advocated by researchers and practitioners which could help in surviving COVID 19 crisis. It summarizes and presents good examples of Belgrade hotel managers.
\end{abstract}

Keywords:

crisis management, hospitality management, proactive managers.

\section{INTRODUCTION}

The dynamism of market, technological, social and other factors of the micro and macro environment make it difficult for management to maintain the optimal structure of supply, organizational structure and technology (Todorović et al., 2003). In recent years, tourism industry worldwide has been hit by crises and disasters. This made the implementation of crisis management one of the crucial factors for survival on the market. COVID-19 is unfortunately the most critical factor affecting the economy, and consequently the hospitality business as well. Many different factors made an irreversible change in tourism industry. Subjects in hospitality business need to be flexible and react to implement the crisis strategy. The problem becomes more complex when realizing that the crisis not only affects operators, but the suppliers, investors, and guests, as well. Crisis management refers to the strategies and tactics by which a company seeks to respond to sudden and significant changes that threaten the survival of the company on the market.
Correspondence:

Aleksić Ana

e-mail:

office@eventplanner.rs 
Crisis situations threaten not only the reputation of the company but also affect profits, stakeholders and a number of employees (Restaurant Manager, 2018). The issue of crisis management is to ensure that, whatever situation occurs, the company will be ready to react and recover as soon as possible. Internal efficiency is primarily determined by the way in which the company organizes the work process, and external refers to the harmonization of business philosophy and value system of the environment. Flexibility of the company implies the ability to use new chances to achieve results, to avoid or minimize the impact of unfavorable activities on business with the lowest possible adjustment costs.

There are also theories, according to which, changes and crises are actually chances for a company and individuals. If management can successfully solve problems, they are no longer problems - they become opportunities. Every problem is a chance at the same time (Adižes, 2012). What is a problem for one company or a competitor is an opportunity for another. The change in the environment causing the crisis also affects competition; because of this, they all have the same problem or have been given the same opportunity. Those who are more capable of change will survive or make a competitive advantage out of the crisis. Crises will make the weak die quickly and the strong become even stronger. The crisis is good for exceptional leaders and companies - those who can successfully cope with it. In times of crisis, their weaker competitors disappear and leave the markets to them.

\section{LITERATURE REVIEW}

Businesses in hospitality industry are characterized by high fixed costs so the risk of loss-making business is higher because of the limitations and reduced funding opportunities from the third-party sources (Pindžo and Genov, 2019). The importance of government support on macro level in external crisis and improved competitiveness and cost reducing activities on the level of the organization, are the activities of strategy for survival in tourism business (Israeli, 2007). Internal activities are cost reducing activities (Israeli, 2007) and important practices in the fields of marketing, hotel maintenance, human resource (Israeli et al., 2011). One of the most important research that evaluated managers activities during crisis was conducted by Israeli and Reichel (2003). They made a list of crisis management practice activities, evaluated the importance managers assign to each practice and also the level to which managers use each practice.

The differences between strategies of local and international hotels were also interesting. Although local hotels are also realizing that crisis management is necessary, their approach is still reactive, while the hotels that were part of international chains were proactive (Sawalha et al., 2013). The concept of management best practices starts by recognizing that crises consists of three stages: "the pre-crisis/disaster stage; crisis/disaster stage; and post-crisis/disaster stage" (Shaluf, 2008; Ritchie, 2004; Faulkner, 2001; Kumar, 2000) The vulnerability of organizations to crises creates the need for thinking of the most effective ways of managing them. There is no unique, universally adopted approach for crisis management that works in all countries, situations and organizations.

Some authors appoint different crisis strategies between branded and fine dining hospitality units (Semercioz et al., 2015). Management activities, such as income and cost reductions, as well as efficiency and competitiveness improvements, are related to reactive or proactive approaches and adding customer value and gaining flexibility by the "branded" fine dining subjects. These activities are leading "branded" fine dining hospitality company to follow two strategies: customer loyalty strategy and price strategy.

Reducing costs is one of the most important topics on the series of webinars organized by the Restaurant Owner Association (Association of restaurant owners in the US) for its members at the very beginning of the crisis. If staying in business, which was the first important result to calculate, they put an emphasis on (Laube and Erickson, 2020): 1. finding cheaper finance sources, 2. cutting expenses in rent, food, beverage and salaries, 3. finding new sources of sales and cash - gift card, promotions, grocery sales, and 4. prolonging payment to suppliers. 
Marketing actions and advice on actions are summarized here:

1. Communication on all levels: managers in hospitality industry realize how important communication on all levels is. Some authors suggested having one or a few spokespersons from different departments who will be in charge of representing the company and the team (Harris, 2018).

2. Care is the main issue: Managers are concerned about the guests but also about the staff and communicating with them: the ones who are there and the ones who are gone. Realizing that the pandemic put focus on isolation, but a physical isolation, not social - meaning people still tend to be in touch (and probably more so even now). One of the main issues when doing business in hospitality is to show compassion, empathy, trust, care, respect, and service to the guests and clients. (Aaron Allen \& Associates, 2014)

3. Communication through blogs and social channels should be on daily basis. Putting videos, films, showing employees are working in safe and clean conditions, putting menu and order button to increase sales, having the right attitude during crisis time, be sustainable and, if possible, even participate in charity for those who are in need during pandemic, such as some restaurants in USA did (delivering donated meals to CORONA workers has helped these restaurant stay in business in 2020).

4. Customer experience is set of emotional, sensorial and physical interactions between customer and company. During the crisis, it is very important to keep customer experience at the same, if not even at higher level. Asking feedback from guests is one of the methods showing engagement and improving experience management.

5. Steps in re-opening - communication with customers. Managers need to communicate what specific steps will be taken to take care of customers and employees during re-openings.

6. New innovative products - keep up with innovations and adjust product to the new era of online events and gatherings. Introducing possibilities for hybrid events (Wikipedia, 2020) - meetings that combine a "live" in-person event with a "virtual" online component.

The issue of this paper is to focus on actions of Belgrade hotels managers during COVID 19 in order to evaluate if they apply some of the best practices during crisis and how innovative they are when fighting with the new type of crisis caused by pandemic. The best practices examples from the literature, used in this paper, are summarized in the Table 1, as presented in (Israeli et al., 2011).

\section{METHODOLOGY}

Less than 30 percent of hotels were open in June in Serbia, 112 out of 380, and due to the pandemic in June the occupancy rate was only 10.16 percent (HORES, 2020). After the end of the period of state of emergency, tourists started visiting all the hotels located out of Belgrade as the borders were closed, so we had a tourist boom and all tourist places fully booked - mountain hotels, rural houses, spas. Statistic data for Belgrade were much different than for the rest of Serbia - in July only $8 \%$ of the accommodation capacity of all hotels in Belgrade was booked. Compared to the number of visitors for July 2019, it was $88 \%$ lower and number of overnights was $82 \%$ lower. From the beginning of the year until July, occupancy was only $13 \%$. Some information indicate occupancy rate for August of only 3\%. Due to the consequences of the COVID-19 pandemic, state of emergency and other restrictions, most hotels and restaurants were closed for three months and had reduced turnover (HORES, 2020). In period of the three months only few hotels were opened - among them Crowne Plaza, Hilton and Radisson Blu. 
Table 1. Practices in crisis management

Sector

\begin{tabular}{ll}
\hline & Laying off employees to reduce labor force \\
Using unpaid vacation to reduce labor force & Reducing the number of workdays per week \\
Human resources & Freezing pay rates \\
& Replacing highly paid employees with new low paid employees \\
& Increased reliance on outsourcing \\
\hline & Marketing to domestic tourists in joint campaigns with local merchants \\
& Marketing to domestic tourists with focus on specific attributes of the location \\
& Price drop on special offers \\
& Reducing list price \\
& Marketing to foreign tourists with specific focus on the location's distinctive features and \\
Marketing & Marketing and promoting new products or services (family events, catering) \\
& Marketing to new segments \\
\hline Cost reduction & Cost cuts by limiting hotel services \\
& Cost cuts by postponing maintenance of the building (cosmetics) \\
& Cost cuts by postponing maintenance of the engineering systems \\
& Extending credit or postponing scheduled payments \\
\hline Government & Organized protest against the lack of government support \\
Industry-wide demand for governmental assistance with current expenses \\
Industry-wide demand for a grace period on tax payments \\
Industry-wide demand for a grace period on local tax (municipality) payments \\
\hline
\end{tabular}

Source: Israeli A., Mohsin A., Kumar B. (2011). Hospitality crisis management practices: The case of Indian luxury hotels, International Journal of Hospitality Management, Volume 30 (2), 367-374. DOI:10.1016/j.ijhm.2010.06.009.

List of hotels was acquired from web pages of Tourist Organization of Belgrade (TOB, 2020) and then web pages were checked one by one. The hotel websites were reviewed if the new marketing strategies were introduced and the hotels with best practices were chosen. Interviewer-administered questionnaire was conducted. Crowne Plaza and Mama Shelter new strategies brought the higher occupancy rate.

Hotel Crowne Plaza reached 20\%, in September, Mama Shelter 16\%, Mona Plaza increased profit by renting rooms as offices, but started renting in September - during July and August they had launched strong marketing campaign so additional source of profit was gained. Metropol successfully started new way of organizing events - online. All four hotels management showed quick, flexible and innovative actions and except profit, assured a good image for the future.

The questionnaire was used to ask managers if they were applying all sets of crisis strategies that were found in literature.

1. All researched 4 star hotels had reduced number of employees, lowered the working days, or paid minimum salaries.

2. All interviewed hotels had described marketing strategy they launched to pool the trigger for arrival of domestic guests. Reopening marketing also plays an important role to communicate new and regular guests.

3. Cost reduction and prolonged payments to the stakeholders.

4. All hotels were using government help except Crowne Plaza which is considered as a big company. The best innovative ideas were found in the following examples: 
Mama Shelter sales team realized that their guests were proactive and innovative, and they would be the first one to start travelling when possible.

1. They used the unfortunate occasion of low occupancy rate to invite corporate clients for an overnight to ensure them Mama was clean and safe and provided them with opportunity to socialize (Mama Shelter, 2020). This example shows intangible measures all in one - communication that shows Mama Shelter is clean and safe but also care for employees, guests and clients.

2. Longer stay - stay long with MAMA, promotions, and lower rates for stays longer than 4 nights.

3. Sex-cation - provocative campaign for couples that inspires domestic travelers to come and refresh relationship. This campaign has been applied in the rest of Mama Shelter (Accor) hotels even in more provocative manner as situation with closed borders and orientation on domestic market has been present in other countries as well.

Crowne Plaza Belgrade was one of the three hotels in Belgrade that were opened during the state of emergency but the only one that was so busy with food preparing and delivery (Crowne Plaza Belgrade, 2020). The idea was born when the campaign "stay at home" started. The focus was on the elderly, so the emphasis was on the cooked dishes. On the other hand, people who worked during the state of emergency could not go shopping and it was easier for them to order. The advertisement showing the staff preparing food with gloves and masks was launched only through social networks and e-mail marketing to associates and came to life within only seven days. As the state of emergency lasted for a long time, they made a closer relationship with customers. Every day there was one cooked dish and several a la carte dishes on the menu. On weekends, customers were waked up with burek and donuts. Every week, sales exceeded expectations. The number of portions sold was 250. Also on weekends, over 180 portions were delivered in the period from 8-10 am and thus made the hotel recognizable in the city by the weekend breakfast.

New products:

1. weekend packages with spa treatment for domestic travelers,

2. events at the open terrace for companies, and

3. online events.

Hotel Mona Plaza was opened just before the crisis began. Sales team was created to be the one of the best on the market and was working hard for almost two years before opening to assure a good business start. The team was realistic with low occupancy rate and came out with two new strategies (Mona Plaza, 2020):

1. Adapted part of the hotel into office space for all corporate clients. They have implemented all safety measures and offered to the clients modern office space in new rooms in the city center. They have found new ideas to reach new source of profit.

2. They realize the importance of trainings and they conducted a film industry training realizing the raising arrival of filming teams in Serbia.

Metropol Palace hotel was the first hotel that made up the tracking of the new formats of events - making the platform for online events and Hybrid events. The "Green screen", equipment for online events is virtual studio which can be adjusted to clients' needs and can host for more than thousand attendees online from all over the world. They communicated this innovation to all clients and promoted it via social networks (Metropol Palace Belgrade, 2020). This made them one of the most popular places for virtual events and singled them out as one of the leaders in this field in the industry. New safe option of traditional gatherings was also promoted - events on the terrace with view of $360^{\circ}$. This was the very first hotel that launched this type of events and they had in total 15 events at the beginning of the season. The number of events and the profit gained is much lower than in case of standard events.

Other hotels starting with the same practice assuming that traditional way of gathering unfortunately will not be possible in the near future. 


\section{CONCLUSION}

The research shows that Belgrade hotels are following the new practices to survive in the crisis situation. Future research should continue to repeat the analysis of adopting measures in all four fields in different hotels in order to make complete information about actions and measures implemented during and after the crisis. Repeating is important, so we can emphasize how much crisis management, flexibility and innovation is important to survive in the hotel business. Guidelines and practice examples are necessary to make path for future crisis as hotel industry is vulnerable to all macro and micro changes.

CORONA became our reality and although there was not much literature in this field and none of the subjects or companies could be prepared for the situation, it is obvious that our industry reacted very fast and came up with new products and new communication ways, putting emphasis on care at all levels. Despite all these efforts, the profits are still lower up to $90 \%$ and the occupancy rate accounts for approximately 10 percent. At this moment, we are listening about new expectations of rising number of the diseased and new fears and limitations in the near future. We realize we will need to learn to live in this new reality, and the future of our business is still under a question mark despite all the efforts.

\section{REFERENCES}

Aaron Allen \& Associates. (April, 2014). 22 Biggest Crisis Communications Challenges in Restaurant History. Retrieved September 10, 2020, from https://aaronallen.com/blog/restaurant-crisis-communications.

Adižes, I.K. (2012). Kako upravljati u vreme krize: (i kako je, pre svega, izbeći) . 2. izd. - Novi Sad: ASEE.

Crowne Plaza Belgrade. (2020). Informacije. Retrieved September 18, 2020, from https://m.facebook.com/ CrownePlazaBelgrade/about/?ref=page_internal\&mt_nav=0\&locale2=sr_RS

Faulkner, B. (2001). Towards a Framework for Tourism Disaster Management. Tourism Management, Volume 22, 135-147. DOI: 10.1016/S0261-5177(00)00048-0.

Harris, C. (2018). How your restaurant can prepare for a crisis. Retrieved April 09, 2020 from https://www. restaurantdive.com/news/how-your-restaurant-can-prepare-for-a-crisis/544125/.

HORES. (June, 2020). 10.06.2020. Saopštenje za medije. Retrieved June 10, 2020, from http://www.hores.rs/vesti.html.

Israeli, A. A. \& Reichel, A. (2003). Hospitality crisis management practices: the Israeli case. International Journal of Hospitality Management, Volume 22(4), 353-372. DOI:10.1016/S0278-4319(03)00070-7.

Israeli, A. A. (2007). Crisis-management practices in the restaurant industry. International Journal of Hospitality Management. Volume 26, 807-823. DOI:10.1016/J.IJHM.2006.07.005.

Israeli A., Mohsin A., Kumar B. (2011). Hospitality crisis management practices: The case of Indian luxury hotels, International Journal of Hospitality Management, Volume 30(2), 367-374. DOI:10.1016/j. ijhm.2010.06.009.

Kumar, G.S.J. (2000). Disaster management and social development. International Journal of Sociology and Social Policy, Volume 20(7), 66-81. DOI: 10.1108/01443330010789007.

Laube, J. \& Erickson, J. (April, 2020). Surviving COVID19- cost cutting and cash flow. Retrieved April 2020, from https://www.restaurantowner.com/public/COVID19-Cutting-Costs-Cash-Flow-Handouts.pdf.

Lew, A.A. (1987). A Framework of Tourist Attraction Research, Annals of Tourism Research, Volume 14 (4), 553-575. DOI: 10.1016/0160-7383(87)90071-5.

Mama Shelter. (2020). Mama protects you from the COVID-19! Retrieved September 10, 2020, from https:// www.mamashelter.com/en/covid-19.

Martilla, J.A. \& James, J.C., (1977). Importance-Performance Analysis. Journal of Marketing, Volume 41(1), 77-79. DOI: $10.1177 / 002224297704100112$.

Metropol Palace Belgrade. (2020). Meetings and Events. Retrieved September 18, 2020, from https://www.marriott.com/hotels/event-planning/business-meeting/beglc-metropol-palace-a-luxury-collection-hotelbelgrade/

Mona Plaza. (2020). OFFice at Mona Plaza. Retrieved September 10, 2020, from https://www.monaplaza.com/ rs/poslovni-prostor-u-centru-grada?utm_source=slider\&utm_medium $=$ site\&utm_campaign $=$.

Pindžo R. \& Genov G. (2019), Menadžment prihoda u hotelijerstvu, Beograd: Institut Ekonomskih Nauka, page 7 
Restaurant Manager. (2018, November 29). Developing a Restaurant Crisis Management Plan for Your Restaurant. Retrieved June 15, 2020 from https://pointofsale.com/developing-a-restaurant-crisis-management-planfor-your-restaurant.

Ritchie, B.W. (2004). Chaos, crises and disasters: a strategic approach to crisis management in the tourism industry. Tourism Management, Volume 25(6), 669-683. DOI:10.1016/j.tourman.2003.09.004.

Sawalha I.H., Jraisat L.E., Al-Qudah K.A. (2013). Crisis and disaster management in Jordanian hotels: practices and cultural considerations, Disaster Prevention and Management. Volume 22 (3), 210-228. DOI: 10.1108/ DPM-09-2012-0101.

Semercioz, F., Pehlivan, C., Sozuer, A. \& Mert, A. (2015). Crisis management practices and strategic responses through customer loyalty and price strategy in hard times: Evidence from fine-dining restaurants. Procedia - Social and Behavioral Sciences. Volume 207 (2015) 149 - 156. Retrieved September 09, 2020, from http:// www.sciencedirect.com. DOI: 10.1016/j.sbspro.2015.10.164.

Shaluf, I.M. (2015). Technological disaster stages and management. Disaster Prevention and Management. Volume 17(1), 114-126. DOI: 10.1108/09653560810855928

TOB. (2020). Hotels. Retrieved November 1, 2020., from https://tob.rs/en/where-to-stay/hotels.

Todorović J., Đuričin D. \& Janošević S. (2003). Strategijski menadžment preduzeća. Beograd: Ekonomski fakultet, Univerzitet u Beogradu, page 430

Wikipedia. (September, 2020). Hybrid event. Retrieved September 18, 2020, from https://en.wikipedia.org/wiki/ Hybrid_event. 